\title{
Possible Geographies: a passing encounter in a café
}

\author{
Eric Laurier* and Chris Philo**
}

\author{
*Institute of Geography, Drummond Street, Edinburgh UK \\ E-mail: Eric.Laurier@ed.ac.uk \\ **Department of Geographical and Earth Sciences, University of Glasgow, UK. \\ E-mail: cphilo@ges.gla.ac.uk
}

\begin{abstract}
Summary: The rise of non-representational theory in human geography has prompted serious questions about how researchers might 'represent' what they encounter in their fieldwork. A central problem is that we reach an insurmountable impasse, an aporia, because we cannot share feelings in a manner faithful to our experience of them or equally that certain spectacular or horrific events and encounters escape their retelling. We argue that this impossibility should not become a warrant for withdrawing from the world, however, and instead propose that close descriptions can still be offered of particular encounters, attending in the process to the situated, embodied sensemaking work being (unavoidably) undertaken by the peoples involved that makes those encounters what they are. Such an approach promises a socio-logical investigation of the partially successful, here and now, 'just-thisness' of things, and we argue that scholars of social life can learn mub from taking seriously how any encounter unfolds without transcendental or structural guarantee in the immediacy of the life-worlds where it is made and re-made.
\end{abstract}

\section{After representation?}

Is the encounter at the heart of fieldwork ultimately unspeakable? Impasses, silences and aporias: these words bring to mind cul-de-sacs, unbridgeable chasms and, as the definition of aporia from Concise Oxford (Fowler et al 2004) puts it, finally 'undecidable meanings'. These are the points at which language find its limits, where cultural geography, having so keenly theorised representation, comes upon matters that mark the end of representation: things, events, encounters, emotions and more that are unspeakable, unwrite-able and, of course, un-representable. It sounds like the threat that it may be all over for the 'cultural turn', but what if we make of that threat a promise instead? A promise of beginning inquiries less fixated on solving or explaining problems in theory with theory. A promise to return to just what our wordy worlds have to offer in their shatterproof transparency, their abundant detail and their living motion. To do what we have elsewhere called 'undefined investigations' (Laurier and Philo 2004); which is to say, investigations that do not begin by defining their phenomenon, but seek instead to learn from the investigation what defining, describing, proving, caring, observing,

\footnotetext{
${ }^{1}$ This paper was originally prepared for a conference session on the theme of 'Im-passable Geographies', the brief for which ran as follows: 'Geographers have always placed the encounter at the heart of their work, be it the encounter with landscape, the other, or the even the tradition itself. However, many different theoretical perspectives converge, at the vanishing point as it were, on the ultimately unspeakable nature of such encounters and thus admit to an impossibility within and resistance to the task of representation. As human geography struggles to go beyond the limitations of positivism and constructivism this aporetic has come to the fore in recent approaches to and accounts of embodiment and performativity. This session seeks papers which engage with such shattering encounters - be they with text, bodies, or landscapes - for the sake of doing justice to our im-possible geographies' (Elden and Harrison 2003).
} 
sharing, encountering or even breakfast (Laurier 2005a) might be. .

Of late there has been a gathering resistance to the task of representation by various constituencies of geographers, ${ }^{3}$ and those resisting such a task are dwelling on the impossibility that is internal to the concept of representation. Resistance to representation and acknowledging its impossibility are two quite different things, however, and they are worth differentiating since each alone is of great import in the warrants and auspices for cultural geography's enterprise. Theorists may well be working out how best to resist representation given that the last two decades in cultural geography have arguably built an edifice upon it. To put it baldly, the claim is that all language is representation, all connection with reality is through representations, and systems of representation have been constructed to mask, distract and serve ideological interests. Representation, for social theorists, has been used as a metaphysical (and political) critique of 'naive' realism. Approaches emerging from Nigel Thrift's (eg. 2000a; 2000b, 2003, 2005) 'nonrepresentational theory' are nonetheless critical of the endless ways in which this notion of representation has dominated cultural geography, and social and cultural research more widely. ${ }^{5}$ Influenced in part by the writings of Ludwig Wittgenstein, they see no need to prioritise criticism of existing representations, nor to undertake the labour of correcting ordinary language or building better representations that will supplant those already in existence (Dewsbury 2003; Dewsbury et al 2002; Harrison 2000, 2002, 2003, 2005).

What then of the second critical line mentioned above: namely, the apparent impossibility within the task of representation? Again to put a subtle idea baldly, the insistence is that there are things that we (humans) can feel, sense and express which are unspeakable, unsayable and unwrite-able. Dance, tears, shock, touch, faces, gestures and more that are indeed aporias, puzzling and yet fundamental to life (Lorimer 2005; McCormack 2002; Thrift 2003). Trying to say or write them, so it goes, inherently loses them. If non-representational theory is moving away from a mimetic to an aporetic sense of language, then the further implication may be that the work of referring to the world is fruitless. Strangely, then, just as Harrison $(2002,489)$ steers us towards a concern for

\footnotetext{
${ }^{2}$ We do not attempt an a priori definition of 'aporia', since our ambition is instead to let practitioners and usage teach us something about it, in a similar manner to how Sacks (1992a) examines proverbs. This being said, it is worth flagging a deconstructionist definition of 'aporia' as 'the sense of a final impasse or paradox: a point at which a text's self-contradictory meanings can no longer be resolved, or at which the text undermines its own most fundamental presuppositions ... leading to the claim that the text's meanings are finally "un-decidable" (Baldick 2003).

${ }^{3}$ Feminist geographers inspired by strands of psychoanalysis and psychotherapy (eg. Bondi 2006, esp.437438; Rose 1999; Thien 2005) have made a related move, in part through prioritising the unconscious seemingly acting 'beneath' the realm of cognition and its representational constructs; but various geographies of practice (eg. Lorimer 2005) are arguably implicated here as well. Alternatively, Olsson's (eg. 1980; 1991) poetic-surrealist geographies have long been setting their face against simplistic assumptions regarding the representability of the world (see Philo 1984, 1994).

${ }^{4}$ We are paraphrasing comments made by Lynch (1993) on constructivist theories and ethnomethodology's different departure from that of deconstruction.

${ }^{5}$ There is a longer-standing critique of the 'correspondence' theory of language, from amongst others Blum and McHugh (1984), Garfinkel and Sacks (1970) and Wittgenstein (1953), and, perhaps of more relevance here, of representation (Lynch 1994b)
} 
the 'rough ground' of practical life, away from what Nietzsche (1977: also Philo 1992, 140) diagnosed as the pull to 'eternals' and 'essentials', he also - brilliantly, troublingly inserts a layer of philosophical complexity, a maze of aporias, essaying the impossibility of researchers ever being more than hopelessly behind, after the event, disingenuously convening representations of things that cannot but elude them. And yet, is there not still a sense in which, precisely on that rough ground representations are part of the animal and the foliage, in that situated peoples are persistently representing their worlds, full of events, contents, joys and sorrows, problems and possibilities, to themselves and to others around them? Thus, despite the seeming impossibility of ever fully, accurately, appropriately representing the 'interiority' of one's world to another, that is precisely what human beings cannot but be striving to do much of the time, whether friends chatting about their day in the café or, indeed, researchers reporting on what they had witnessed in the field. ${ }^{6}$ In the process, an impossibility becomes multiple possibilities; and, moreover, the representational work being undertaken - certainly through words spoken, if less so in words written - is rarely only accomplished through what is said, and rather is commonly occurring hand-in-glove with gestures, facial expressions, modulations of tone, manipulations of objects-to-hand, and so on. ${ }^{7}$

The upshot is to see representation as a completely possible set of practices, one correlate of which is greatly to expand our understanding of the terrain of representation beyond the word, spoken or written. But, this claim must be taken with care, because we are precisely not then suggesting that everything be regarded as representation: that everything taking place is really one manifestation, symbolisation or whatever of some all-encompassing representational economy from which humans cannot escape (which would be to echo the worst excesses of certain strands in cultural studies). Instead, our view is that very many practices are indeed non-representational, and moreover that many elements of language-in-use, particularly but not exclusively as it tumbles forth in routine conversations, are non-representational as well. Many words, phrases, sentences are hence about orientating oneself in a conversational encounter (Laurier 1999, 2001), jointly with an interlocutor working out a way of proceeding in the interaction, of keeping the conversation going; while much of the work that the content of language does - certainly in everyday contexts, such as stating, telling, declaring, bemoaning, joking and so on - is not straightforwardly representational (or is only 'representational' if we extend the meaning of representation to the point of meaninglessness). Perhaps unexpectedly, then, while on the one hand allowing an expansion of (what we understand

\footnotetext{
${ }^{6}$ We are troubled by how Harrison's $(2003,2005)$ concern about the essential non-representability (even non-relationality) of (extreme) emotional experience seems also to double as his justification for why there are these impassable limits in the social-scientific project. While it is doubtless true that someone in severe grief cannot fully convey the intensity of that emotion in words, it indeed being ineffable, does this aporia necessarily mean that no attempt can or should be made by a researcher to describe something of what that person is going through (of what their tears, perhaps shed in a public place, might reveal about their experience and how it then impacts upon others around them)?

${ }^{7}$ This representational work might be described as 'performative', although we have some reservations with this approach when it starts to imply a deeper, hidden 'scripting' of conducts, appearances, etc., that diverts our attention from what is actually being done here-and-now (see also Laurier and Philo 2006).
} 
by) representation, to include many non-wordy practices, we are on the other hand simultaneously proposing a certain narrowing of the concept as well, so that not all wordy practices are included.

In fact, what we are really suggesting is that on the rough ground of practical life, all kinds of representational and non-representational work are always going on, bumbling along together, mutually supporting one another or perhaps sometimes undermining one another, in a fashion that can (and should) never be sorted out in some neat a priori fashion by theorists of either representation or non-representation. In the usual academic rush to consult theorists and literatures, as has happened - productively for the most part, we would judge - in the non-representationalist assault on representation, there has nevertheless been a curious whiff of 'purification': of wanting to return to first principles, where much that 'goes on' in worldly contexts seems to be theoretically impossible, even as edicts are issued about the importance of visiting the lived-in world where, to the 'untutored', much still seems entirely possible. Thus, while there has been the thrill and the communal spirit of the dash to the library, less effort has been expended in sieving through the rough granules and sticky textures of actual events, encounters and places. In the ceaseless flow of life, 'our' privilege and even point as researchers is surely that we can take the time to examine details-at-hand which, in painstaking ways, could teach us about so many classic topics of the social sciences and humanities: imagination, explanation, description, perception, memory, expression, performance, definition, emotion, cognition, information and, of course, representation ${ }^{8}$. Representation, as one of the grand concepts and one that cultural geography has fixed upon and been fix(at)ed by, can fruitfully be investigated in the worldly activity of 'representing', which is both more and less than the production of words, spoken or written; in that more than words can be involved in the representing, but also that the words involved will not only be representing.

Considering an actual encounter, event or occasion will seem pointless if we assume that we either already know what is representation (a priori and reductively) or we accept that imaginary events and places will be sufficient. By imaginary, we mean the just so' examples that we sometimes use in discussing and thinking about, for example, what people do in cafés. Indeed, our imaginations are limited not just by our personal foibles, but also by what we can commonly agree is likely, regardless of whether it is actually so in a particular case. By way of contrast, the world is inexhaustibly detailed and full of surprises that are only revealed in engagements with it in its specificity, not in the toyexample demonstration. So, before we are accused of sorting out conceptual problems by stating the facts or testing hypotheses, an engagement with empirical matters is undeniably necessary. This move is not for such positivistic reasons as showing that, say,

\footnotetext{
8 The demand that we consult local experts and practically competent members has come from Latour (1999) in ethnographic studies of science and technology; and from Lynch (1994a) and Garfinkel and Wieder (1992) as 'Sack's gloss'; and, albeit rather differently, from Foucault (see Laurier and Philo 2004b) in how he does his histories of reason, sexuality and discipline, where he effectively brackets reason, etc., and turns to history to respecify these classic topics as non-transcendental and not-metaphysical.
} 
representations refer to something 'real', what Edwards et al (1995) call 'death and furniture' demonstrations; instead, the importance of such a move, be it field-based, archival, musical, statistical or laboratory, is to do with retrieving the 'missing what' of ethnomethodology (Laurier 2001). In what follows, then, we are not going to begin by finding a suitable example of representation; rather, we wish to look at an encounter where a 'telling-off' occurs to present the worldly logic by which such a telling-off can be done here and at this time, recognised as such by the participants, and what can be done with this mutual recognition. We will briefly explore an instance of language-in-use, and show that language is orderly and ordering at source, in a typical encounter from an ordinary place, to remind us that there is much to learn from continuing to revisit the places that (we assume) we already know. Finally, we will hint at the place or life-world in which telling-offs, as well as inquiries into them, are, after all, possible.'

\section{A café encounter}

Cafés, sometimes quiet, sometimes buzzing and sometimes empty: we have been investigating these places because events happen there, encounters happen there day-in, day-out (Laurier and Philo 2006). Thinking about cafés brought us to appreciate that there are a diversity of encounters: with friends, with acquaintance, with neighbours, strangers and staff. There is an ordinal logic to encounters, they have qualities according whether they are for the first time, where their first time status is a special characteristic, a second time, a third, and that this declines. Let us make that distinction for a start - a first time encounter from a second or a third. Clearly, there is a point where encounters positioned in a sequence fall away from relevance for participants ('it was the twentyfourth time I bumped into him in Starbucks'). Before we shift to our description of an actual encounter, we must also note the distinction between arranged encounters (eg. business meetings, blind dates) or chance encounters (eg. sharing a table, making small talk in the queue). Each possible formulation and categorisation of an encounter comes with different consequences and expectations; and, with this in mind, let us now close in on a question: 'how is it that any person could go about working out what kind of encounter they are having at the time they are having it?' While this might not appear to be a live issue, consider what happens when you meet someone who you do not recognise, but who nevertheless claims that this is the second time you have met. Do you not spend considerable time and effort settling the matter?

Rather than using imagined scenarios any further than to draw readers into a topical terrain, here now is a first encounter between EL and another customer in a café:

'Don't bite your nails,' says a voice out of the corner as I'm faffing around on my laptop with the formatting of my research journal. It's the woman from the table across from me - the one

\footnotetext{
${ }^{9}$ Echoing here Blum et al's $(1974,122)$ analysis of snubs: 'this paper presents (a) rules for seeing snubs, (b) a grammar in terms of which snub is applicable, (c) a community in terms of which snub is conceivable; and presents these only with the intention of making reference to our game, ie., to speak that which makes possible [our emphasis] our analysis.'
} 
with the fur hat.

It takes me a moment to focus. She has stopped by my table on her way out of the café.

'Don't bite your nails. I was watching you,' she says again.

'Eh, well it stops me smoking,' I finally reply, a bit disconcerted since I'm supposed to be the nosey one here. She laughs a little.

'Well you'll have to stop or it'll be, eh, bitter almond on your fingers.'

'Ob yes bitter almond,' and I laugh a little too. Seeing and then trying not to focus on the little beard and moustache that she has and that I can now see close-up.

'Well I try not to but when I'm concentrating on something I tend to...'

She glances at the screen of the laptop. I worry briefly that she'll read what I've been writing

about but then realise that I've shifted pages so it's not on the screen.

'They're great these laptops aren't they,' she says.

(Excerpt from field journal, February 2003) ${ }^{10}$

In any such first encounter in a café, we cannot know at the time whether it will be the beginning of an acquaintanceship, based perhaps on both being regulars at this café. Nor, relatedly, can we be sure whether it will be a likely one-off meeting in the way that characterises so many encounters in the city; but remember that all of our closest friendships and working relationships began with a first encounter wherein, at the time, there was no way of knowing the future that would follow. An encounter of this kind can therefore carry with it the mild anxiety over its importance, its orientation to the future, and in the café, if you have talked to another regular customer once, from then on rights (and the possible pleasures and annoyances) of subsequent recognition follow.

There is a kind of impasse here that the woman customer has solved. You fancy chatting to a customer who you have never met before in the café, but by the conventions of city life you cannot randomly begin to talk to another; rather, you ought to have a reason of some kind for starting a conversation with them, the most obvious and powerful being that you have met before and thus you can already claim to be acquainted. Here is a café full of customers who you have never met. That it is a café and not the street or a private residence or a petrol station helps. Even with café's expectation and acceptance of conviviality you cannot just say 'Hi there!' to people at random in cafes - they will ask, 'do I know you?' - how can you get an encounter

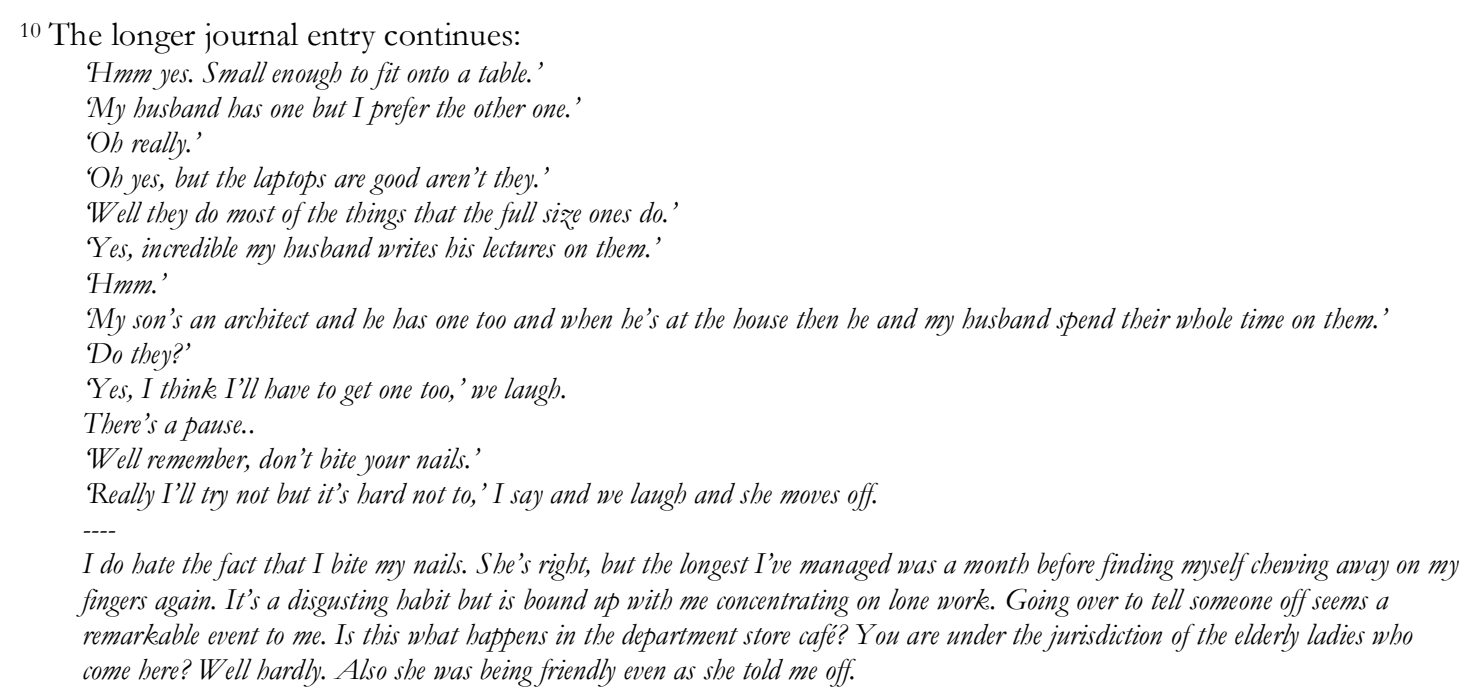


started with them if, say, you do not have, say, an 'accident' to use (bumping into one another, spilling coffee on someone)? The risks are that we may appear disrespectful, invading someone's privacy (in public places), soliciting, chatting up, conning or 'mad'. And a further risk is that we may be rebuffed. There is not the space here to deal fully here with the uses of a 'crowd' (see Laurier and Philo 2004a); but two quick points are, first, that amongst the 'old' crowd of this café, EL was noticeably younger, even though in his 30s, and secondly, he had noticed the woman previously because she was wearing a fur hat in a well-heated department store. Nor is there the space to deal fully with how EL noted down at the time both her fur hat and her facial hair as possible signs of eccentricity or mental illness, a noting that we realise is itself highly problematic (in the light of other research by one author: eg. Parr et al 2004). Let us just register these small details for the time being.

In the vignette from the fieldwork the fur-hatted woman used two 'observables' about EL: the nail-biting and the laptop on his table, the former her playful telling-off. One way for her to initiate some talk with this 'stranger' - although 'other customer' is really the more setting-relevant identity here - was to take EL's nail-biting as a resource to build what Harvey Sacks (1992a\&b) called a 'standardised relational pairing' of what kind of person is talking to what other kind of person. That is, it is not just anybody's job to do tellings-off or the giving of advice in public places, it is only a certain person's responsibility to make such comments (eg. 'elders and betters', or perhaps other relevant kinds of persons such as 'locals', 'staff, 'police'). This does not mean that such persons always will do a telling-off, jokey or otherwise, but they can, these persons also having to analyse the scene to locate themselves as incumbent with, for instance, a 'moralised' paired relationship of elder to a younger (Jayyusi 1984).

How is it that what happened can be cast as a playful telling off? We would suggest a serious telling off would be invited by, say, blowing cigarette smoke in the face of a nearby customer, smashing bottles in the street or putting your feet on the seats of a railway carriage; and a serious telling-off would get its force not only from that to which it was responding, the 'unreasonableness' of another's actions, but also from how it was delivered and then backed-up. Biting your nails is of a lesser order than many infractions, but is still something that can, on certain occasions, be the subject of a reprimand from a person finding themselves to be in the relationship elder to younger. Moreover, there is the possibility that a regular of a café, someone for whom the café has becomes one of their places, albeit in a different way to their home residence ${ }^{11}$ or desk at work, may have acquired situated 'rights' to do a telling-off in public of a new customer (eg. 'you're standing in the wrong place to pay'). Indeed, their telling off verges on advice from the

\footnotetext{
${ }^{11}$ See Stokoe's (2003) incisive work on the use of the category 'young single woman' in the context of neighbours having disputes; and also in an analysis of the neighbour's entitlement to complain about the duration and intensity of visible activities such as bad cooking smells, hanging out washing and slamming doors (Stokoe and Wallwork 2003).
} 
'knowing' to the 'unknowing. ${ }^{12}$ As an aside, these kinds of senses of possession of and responsibility for public places have interesting consequences, for instance in terms of how we might think about other places where nobody would feel like they should tell wrong doers-off or to offer advice to visitors, tourists and new arrivals.

While stretching away from this particular encounter, we can also speculate here on whether this woman who does the mildly humorous chiding of EL when initiating an encounter can obtain something comparable to what we have gained from it. Her initiation of an encounter has a prospective accountability in that she has made something happen. Where nothing very much was happening, she has produced an event, a minor one admittedly but still a 'something', to tell later, as when a wife goes home to her husband and talks about the 'young man' who she teased in the café today. An event like this has value for those of us who are in danger of having lives where, when asked 'what did you get up to today?,' we have no story to tell. These questions are part of regular pointed inquiries during problematically categorisable periods of our life, such as unemployment, retirement, bereavement and old age, which may raise the concern of significant others as to whether we are still active, busy, getting out the house and so on. ${ }^{13}$ For EL's part, this encounter has value since he has an event to record in his field journal: alongside encounters being at the heart of human geographical inquiries, eventless fieldwork is surely an impossible project. For our joint purpose, this encounter now has value as the focus for discussion in an academic paper.

A further impasse that keeps us from talking to strangers is the worry that we may get stuck beside/with or impose ourselves upon another person when the conversation runs dry, becomes boring or various other hazards of sociability arise. We can and do start conversations using features that may, if necessary, assist us in getting out of the encounter (in several senses). In this case the woman is in motion, leaving the café, walking towards an anticipated destination, the exit, and her course of bodily, oriented action has its projectable and anticipated conclusion which can play its part in accomplishing the end of the conversation with me (Laurier 2005b; Mondada forthcoming). The woman in the café is visibly underway in her leaving of the cafe, not heading towards the seat across from me to begin her stay at the café, which might held for both her and EL the promise of further, maybe protracted conversation. In what she is venturing, it is understood by both her and EL to be a passing conversation, and this is how she uses her 'going on' to avoid any impasse. When we look at what is occurring in the café, what we can apprehend is how it is bound to what we can do next on the basis of what we see already underway, and what we can do is indeed done with a sense of how we will be held accountable for what we are doing (these are classic ethnomethodological concerns: Garfinkel 1967; Sharrock and Anderson 1986). By the woman's signalled course toward the café door, following at the close of her time sitting

\footnotetext{
${ }^{12}$ Our thanks to Kathleen Haspel for sharing various field stories of being 'told off in New York for doing things in this particular place incompetently.

${ }^{13}$ See, for instance, the projections of old age offered in Haim (2002), reporting research based on interviews carried out in cafés.
} 
drinking coffee, what she is saying to EL is formulated, even more precisely than passing comments, as parting remarks. It clearly does not bear the consequences of making opening remarks at the outset of sitting and sharing a table with another customer (Cavan 1966; Laurier et al 2001).

We will have to depart from recounting this story of a café encounter without yet having finished a full analysis of it, but hopefully some flavour has been given of how we might speak of it later in terms of speech that was inextricably involved in making sense of and assembling what was happening. We see then that the human practices of (in this case unsolicited) advice-giving and/or telling-off creates the possibility of beginning a public relationship and on particular terms as an older to a younger or a wiser to a beginner. ${ }^{14}$ In various ways from this café vignette we can see how an encounter is 'got going', and once got going in this way can only easily go in certain direction. We come upon how the encounter is bound up with a concern for its future speakable qualities or 'storyable' characteristics (Sacks 1992a; 1992b) elsewhere to other audiences, and also gestures to the differing kinds of 'projects' that we have as an older married woman and as an ethnographer studying cafés.

\section{Unspeakable or uncertain?}

Uncertainty bedevils the inquiries that follow from an encounter like the one we have described: was that what we really saw, and how can we be sure that the woman was seeking stories to tell later? It is a 'natural' inquiry into what anyone can see happening in public places, and at the same time it is an exercise in the grammar of uncertainty rather than of, say, impossibility. We could treat what actually happened in an encounter as impossible to have the final word about, indeed we do treat a first encounter with someone as ripe with uncertainty and speculation. The woman might be just being friendly because she is lonely or she might be mentally ill, which is another possible version of what happened that we have not pursued here, one that we would resist, but one that might be advanced (Cuff 1980; Smith 1978). At the same time, our (ethno)inquiry into what an ethnographer can see in a public place turns upon the methods that any competent participant in everyday life, any 'member' in ethnomethodological terms, routinely deploys to see events in cafés and to tell stories about them later (Sacks 1992a). Thus, the woman in the café does not halt in the face of the impossibility of speaking in her encounter or, we conjecture, of her encounter later. The question may then become what is that we are doing when we tell stories like these, which are about 'here's what I saw and wasn't it slightly odd? well what was going on there today?.' ${ }^{15}$

\footnotetext{
${ }^{14}$ Writing on snubs, McHugh et al $(1974,123)$ say of a greeting by the already acquainted that it 'creates the possibility of acknowledging a public relationship', but such a second encounter cannot but have its possibility in a first meeting such as this one.

${ }^{15}$ Here we might build on Sack's (1992b) analysis of a woman describing what she reckoned might have been the aftermath of a robbery at a department store where she worked.
} 
The desire to know more of public encounters than we normally know is endemic to the sceptical treatments usually given by social scientists of such encounters and, more generally, of conduct in public places (Hester and Francis 2003). When these investigators declare themselves to have reached an impasse, it is likely because they feel unable to decide whether the empirical evidence before them - for instance, of elderly people gossiping in a department-store café - can verify or not their theories of, say, the contemporary recomposition of a Habermasian public sphere or the performance of Goffmanesque 'staged' relations in public (as we discuss in Laurier and Philo 2006). Yet, when we declare that we reach an impasse on what the woman was really up to, this is a perfectly ordinary impasse reached in how we gather up these witnessed events, these moments in our experience of public city life, as would anybody looking in on such a fleeting café encounter. The desire still remains for us, but also for anybody, to tell what we see as stories to certain persons, and in so doing ongoingly to appraise in any description how it is that we could or should be sociable with others in places like cafés, bars, airports, and streets and so forth (Laurier and Philo 2006, forthcoming).

Socrates used aporias to force his students to confront their ignorance, to show that some puzzles were unsolvable or confusing, and to invite his audience to adopt an attitude of humbleness and awe at the wonder of the world. Alongside aporias, in his 'dialogues' there was a push toward the mundane and near-at-hand, finding ways of approaching an idea that escapes the conventions of 'big' Philosophy. ${ }^{16}$ Writing about Gunnar Olsson's work some years ago, one of us remarked that:

I cannot help but see the box marked 'Philosophy' as floating in a strangely unmoored manner above the much less box-like, much less neatly compartmentalised, regions of the everyday world: a realm of mess and fuss, chaos and charm, joy and despair, power and resistance, difference and desire ... [1]t might be that questions about (say) epistemology, ontology, and morality can best be answered, not by consulting the exalted words of the great philosophers, but by examining the everyday epistemological procedures, ontological assumptions, and moral judgements being made by specific peoples situated in specific times and places (Philo 1994, 245).

Having learned from Olsson about the impossibility of language as the representational success that convention demands (or at least hopes) it to be, given its rigidities before a reality in which 'bats' can often be 'mice' and vice versa, this statement entails a 'sigh' about then proceeding - again and again - to revisit the claims of the great Philosophers, rather than looking elsewhere. It voices the wish to turn instead towards the jumble of everyday

\footnotetext{
16 We have noted previously Sack's (1992a) remarks on the limits of what theorists using their imaginations might consider as likely, the point being to escape the limits of what is merely likely, acceptable or conventional. The self-reflective school put it thus: 'Socrates introduced the analytic tactic of examining near-at-hand and mundane examples in order to fasten the mind on the essential features of a problem which the example covers over. Yet his interlocutors invariably resisted this strategy on the grounds that they did not see the connection between the mundaneity of the examples and the idea towards which he was leading them. They did not see that the example neither described nor defined the idea, but served instead to re-route the mind so as to approach the idea in a way that was unencumbered by the conventions of ordinary formulations' (McHugh et al 1974, 109).
} 
life-worlds where people have no choice but to 'get on with it', and in so doing to be solve the 'crisis' of representation in and through countless instances of representing 'something', however imperfectly, to others around them, in words and deeds, sayings, storyings and associated gestures, grimaces and vocal modulations. In the process, the question also arises as to where, if at all, representing is occurring in our café encounter. Quite what is being occasioned here, however, will be obscured if we take everything as clearly and obviously representational or indeed non-representational. Rather, for us, the world is repaired and patched together with a tapestry of stitches, threads and patterned bits of material that cannot but always entangle such neat theoretical either/or stipulations.

The quote above chimes well with the Wittgensteinian move to rough ground proposed by Harrison $(2002,2003,2005)$ and other non-representationalists, and yet non-representational theorists risk becoming preoccupied with the representational aporia as that which cannot be by-passed because every Philosophical route about, around, to one side, over or under it is doomed to failure. Yet, even with this in mind, routes can be found, not straightforwardly directed by Philosophy maybe, and hence (we know) always flawed, under rainclouds, following creased maps, frequently tripping over hillocks and open to defeat by reason. These are grand voyages made just around the corner, down the street or across the room predicated on close empirical attendance to 'stuff happening', and to the arrays of human (and sometimes animal) practice - not just in our comfortable cafés, maybe even in the face of terrible adversity (cf. Harrison 2003, 2005) - inevitably, unavoidably, necessarily integral to the making of these worldly moments. Arguably, then, as researchers, we wish to inhabit what Michael Joyce, an analyst of networks and hypertext, has called 'aporetic space', for us something grounded in life-world encounters great and small, as 'the space of doubt, scepticism, and consideration which eventually yields possibility [our emphasis], valorisation, persistence and meaning. ${ }^{17}$

\section{Acknowledgements}

This paper arises out of empirical and conceptual material related to the 'Cappuccino Community: cafes and civic life in the contemporary city' (ESRC grant R000239797). A version was given at the 'Im-passable Geographies' session held at the RGS-IBG Annual Conference in London, September 2003, and a precis at a one-day workshop on the same theme held in the Department of Geography, University of Durham, January 2004. Thanks to Stuart Elden and Paul Harrison for organising both events, and to participants for their generous questions and suggestions. Huge thanks are also due to Paul for sharing his unpublished work with us, and for the debate.

\section{Bibliography}

Blum A and McHugh P (1984) Self-reflection in the arts and sciences (Humanities Press, Atlantic Highlands)

Baldick C (ed.) (1996) The Concise Oxford Dictionary of Literary Terms (Oxford University Press,

${ }^{17}$ From http://www.cddc.vt.edu/lol/Joyce/M.Joyce.OtherMinded.lo198/OtherM18.html, accessed September 2003. 
Oxford)

Bondi L (2005) 'Making connections and thinking through emotions: between geography and psychotherapy' Transactions of the Institute of British Geographers 30, 433-448

Cavan S (1966) The liquor license, an ethnography of bar behavior (Aldane, Chicago)

Cuff E C (1980) Some issues in studying the problem of versions in everyday situations (Department of Sociology, University of Manchester, Manchester)

Dewsbury J D (2003) 'Witnessing space: knowledge without contemplation' Environment and Planning A 35, 1907-1932

Dewsbury J D, Wylie J, Harrison P and Rose M (2002) 'Enacting geographies' Geoforum 33, 437441

Edwards D, Ashmore M and Potter J (1995) 'Death and furniture: the rhetoric, politics and theology of bottom line arguments against relativism' History of the Human Sciences 8, 25-49

Elden S and Harrison P (2003) 'Im-passable geographies' session abstract for 'Im-passable Geographies', conference session at the RGS-IBG Annual Conference, London, September 2003

Fowler H W, Fowler F G and Pearsall J (eds) (2004) Concise Oxford English Dictionary (Oxford University Press, Oxford)

Garfinkel H (1967) Studies in ethnomethodology (Prentice-Hall, Englewood Cliffs, NJ)

Garfinkel H and Sacks H (1970) 'On formal structures of practical actions' in McKinney J C and Tiryakian E A (eds) Theoretical sociology: perspectives and developments (Appleton-Century-Crofts, New York)

Garfinkel H and Wieder D L (1992) 'Two incommensurable, asymmetrically alternate technologies of social analysis' in Watson G and Seiler R M (eds) Text in context: contributions to ethnomethodology (Sage, London)

Haim H (2002) 'The home over the hill: towards a modern cosmology of institutionalization' Journal of Aging Studies 16, 323-345

Harrison P (2000) 'Making sense: embodiment and the sensibilities of the everyday' Environment and Planning D: Society and Space 18, 497-517

Harrison P (2002) 'The Caesura: remarks on Wittgenstein's interruption of theory, or, why practices elude explanation' Geoforum 33, 487-503.

Harrison P (2003) 'How shall I say it...?' singularity, exposure and compassion' presented paper at 'Im-passable Geographies', conference session at the RGS-IBG Annual Conference, London, September 2003

Harrison P (2005) 'How shall I say it...? relating the non-relational' unpublished ms. available from the author

Hester S and Francis D (2003) 'Analysing visually available mundane order: a walk to the supermarket' Visual Studies 18, 36-46.

Jayyusi, L (1984) Categorization and the moral order (Routledge \& Kegan Paul, London)

Latour B (1992) 'Where are the missing masses? the sociology of a few mundane artefacts' in Bijker W L and Law J (eds) Shaping technology/building society (MIT Press, London: MIT)

Latour B (1997) Aramis, or the love of technology (Routledge, London)

Latour B (1999) Pandora's hope: essays on the reality of science studies (Harvard University Press, London)

Laurier E (1998) Geographies of talk: 'max left a message for you' Area 31, 35-48

Laurier E (2001) 'Why people say where they are during mobile phone calls' Environment and Planning D: Society and Space 19, 485-504

Laurier E (2005a) 'A café as it happens: having breakfast out' unpublished ms. available from the author

Laurier E (2005b) 'The end of the occasion' online paper at: http:///web.ges.gla.ac.uk/ elaurier/cafesite/texts/occasion.html

Laurier E and Philo C (2004a) 'Cafés and crowds: the problem of cosmopolitanism' online paper at: http:///web.ges.gla.ac.uk/ elaurier/cafesite/texts/crowds.html

Laurier E and Philo C (2004b) 'Ethno-archaeology and undefined investigations' Environment and Planning A 36, 421-436

Laurier E and Philo C (2006) 'Cold shoulders and napkins handed: gestures of responsibility' Transactions of the Institute of British Geographers (vol. and page nos. not yet available) 
Laurier E and Philo C (forthcoming) "A parcel of muddling muckworms: revisiting Habermas and the early-modern English coffee-houses' Social and Cultural Geography

Laurier E, Whyte A. and Buckner K (2001) 'An ethnography of a café: informality, table arrangements and background noise' Journal of Mundane Behaviour 2, online at: http://mundanebehavior.org/issues/v2n2/laurier.htm

Lorimer H (2005) 'Cultural geography: the busyness of being more-than-representational' Progress in Human Geography 29, 83-94

Lynch M (1993) Scientific practice and ordinary action: ethnomethodology and social studies of science (Cambridge University Press, Cambridge)

Lynch M. (1994a) 'Laboratory space and the technological complex : an investigation of topical contextures' in Star S L (ed.) Ecologies of knowledge: work and politics in science and technology (State University of New York Press, New York)

Lynch M (1994b) 'Representation is overrated : some critical remarks about the use of the concept of representation in science studies' Configurations 2, 137-149

McCormack D P (2002) 'A paper with an interest in rhythm' Geoforum 33, 468-485

McHugh P, Raffel S, Foss D C and Blum A F (1974) On the beginning of social inquiry (Routledge and Kegan Paul, London)

Mondada L (forthcoming) 'Deixis spatiale, gestes de pointage et formes de coordination de l'action' in Barberis, J-M and Manes-Gallo, M-C (eds) Verbalisation de l'espace et cognition situee: la description d'itineraires pietons (Editions CNRS)

Nietzsche F (1977) A Nietzssche Reader (Penguin, London)

Olsson G (1980) Birds in egg/eggs in bird (Pion, London)

Olsson G (1991) Lines of power/ limits of language (University of Minnesota Press, Minneapolis)

Parr H, Philo C and Burns N (2004) 'Social geographies of rural mental health: inclusions and exclusions' Transactions of the Institute of British Geographers 29, 401-419

Parr H, Philo C and Burns N (2005) "Not a display of emotions': emotional geographies of the Scottish Highlands', in Davidson J, Bondi L and Smith M (eds) Emotional Geographies (Ashgate, London)

Philo C (1984) 'Reflections on Gunnar Olsson's contribution to the discourse of contemporary human geography' Environment and Planning D: Society and Space 2, 217-240

Philo C (1992) 'Foucault's geographies' Environment and Planning D: Society and Space 10, 137-161

Philo C (1994) 'Escaping Flatland: a book review essay inspired by Gunnar Olsson's Lines of power/ limits of language' Environment \& Planning D: Society and Space 12, 229-252

Rose G (1999) 'Performing space' in Massey D, Allen J and Sarre P (eds) Human geography today (Polity Press, Cambridge)

Sacks H (1992a) Lectures on conversation, Vol. 1 (Blackwell, Oxford)

Sacks H (1992b) Lectures on Conversation, Vol. 2 (Blackwell, Oxford)

Sharrock W and Anderson B (1986) The ethnomethodologists (Tavistock, London)

Smith D (1978) "K is mentally ill: the anatomy of a factual account' Sociology 12, 23-53

Stokoe E H (2003) 'Mothers, single women and sluts: gender, morality and membership categorisation in neighbour disputes' Feminism and Psychology 13, 317-344

Stokoe E H and Wallwork J (2003) 'Space invaders: the moral-spatial order in neighbour disputes' British Journal of Social Psychology 42, 551-569

Thien D (2005) 'After or beyond feeling? a consideration of affect and emotion in geography' Area $37,450-456$

Thrift N (2000a) 'Afterwords' Environment and Planning D: Society and Space 18, 213-255

Thrift N (2000b) 'Non-representational theory' in Johnston R J, Gregory D, Pratt G and Watts M (eds) The dictionary of buman geography (4th ed.) (Blackwell, Oxford)

Thrift N (2003) 'Summoning life' in Cloke P, Goodwin M and Crang P (eds) Envisioning buman geographies (Arnold, London)

Thrift N (2005) 'But malice aforethought: cities and the natural history of hatred' Transaction of the Institute of British Geographers 30, 133-150

Wittgenstein L (1953) Pbilosophical investigations (Blackwell, Oxford) 